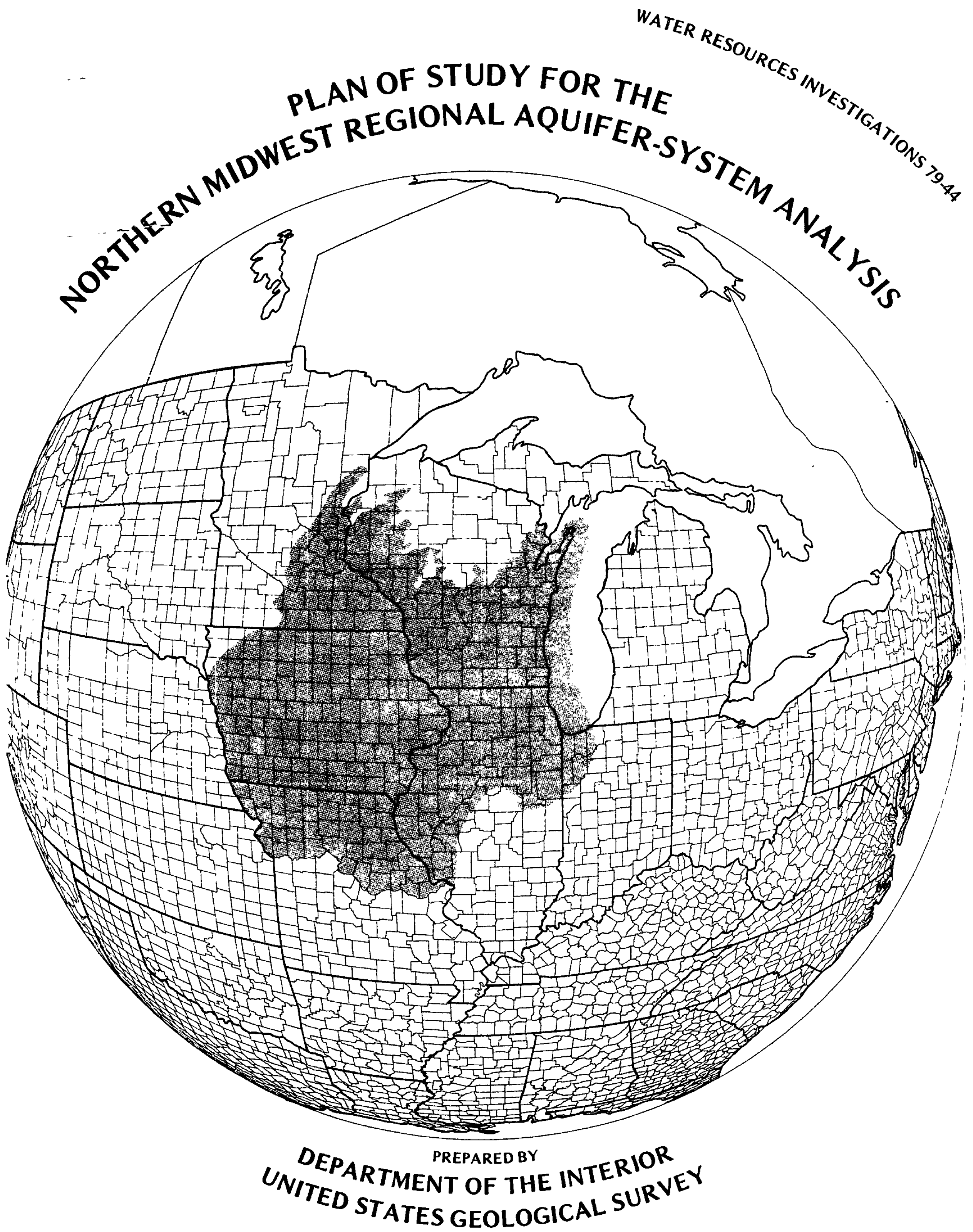





\section{PLAN OF STUDY FOR THE NORTHERN MIDWEST REGIONAL AQUIFER-SYSTEM ANALYSIS}

W.L. STEINHILBER and H.L. YOUNG

U. S. GEOLOGICAL SURVEY

Water Resources Investigations 79-44

APRIL 1979 


\section{UNITED STATES DEPARTMENT OF THE INTERIOR}

CECIL D. ANDRUS, SECRETARY

\section{GEOLOGICAL SURVEY}

H. Willam Menard. Director

\section{Open-File Report}

For additional information write to:

U.S. Geological Survey

Northern Midwest Regional Aquifer Study

1815 University Avenue

Madison, Wisconsin 53706 


\section{CONTENTS}

$\underline{\text { Page }}$

Abstract-- 1

Introduction--

Problem--_-_-

Objectives---

Approach--

Organization---------

Relation to other studies-_-_-

Area of study--

Plan of study--

Computer models-_-_-_-_-_-

District work plans-_-_-_-_-_-_-_-_-_-_-_-_-_-_-_-_-_-_-_-_-_

Illinois----

Indiana--

Iowa--

Minnesota--

Missouri-_-_-

Wis consin-_-_-_-_-_-_-_-_-

References-_-_-_-

\section{ILLUSTRATIONS}

Figure 1. Map showing location and general bedrock geology of the northern Midwest regional aquifer study

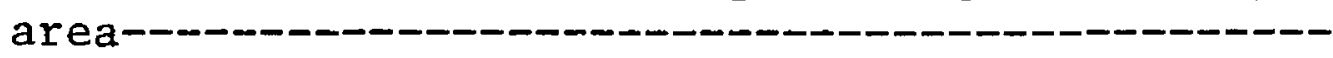

2. Graph showing schedule of major work elements----- 


\title{
PLAN OF STUDY FOR THE NORTHERN MIDWEST REGIONAL AQUIFER-SYSTEM ANALYSIS
}

\author{
W.L. STEINHILBER and H.L. YOUNG
}

\begin{abstract}
Sedimentary rocks of Cambrian and Ordovician age form a major aquifer system in most of Wisconsin and Iowa, northern Illinois, northwestern Indiana, southeastern Minnesota, and northern Missouri. Many metropolitan areas depend on the aquifer for all or part of their water supplies. Declines in potentiometric head have been large in the most heavily pumped areas, most notably Chicago, Milwaukee-Waukesha, Minneapolis-St. Paul, and Des Moines.

Protection and management of the aquifer system are important concerns of State and local planning, regulatory, and water-management agencies. A thorough understanding of the aquifer system is needed for sound management decisions. Thus, a 4-year study of the aquifer, beginning in October 1978, is included in the U.S. Geological Survey's program of Regional AquiferSystem Analysis. The study will evaluate the aquifer's water-supply potential, describe its water quality, and, through computer models of the ground-water flow system, provide the means to evaluate regional aquifer response to different patterns of ground-water development. This report describes the objectives, work plan, and organization of this study.
\end{abstract}

\section{INTRODUCTION}

Sandstone and dolomite strata of Cambrian and Ordovician age comprise much of the sedimentary bedrock overlying the Precambrian basement in the northern Midwest and form the major Cambrian-Ordovician aquifer system. In Minnesota the related Hinckley Sandstone of Precambrian age also is included. Cambrian and Ordovician sediments were deposited in shallow seas on the Precambrian erosional surface, which slopes away from a relatively high area known as the Wisconsin Arch. The oldest rocks crop out in an arcuate pattern around the arch, but are buried by successively younger rocks away from the arch (fig. 1). 


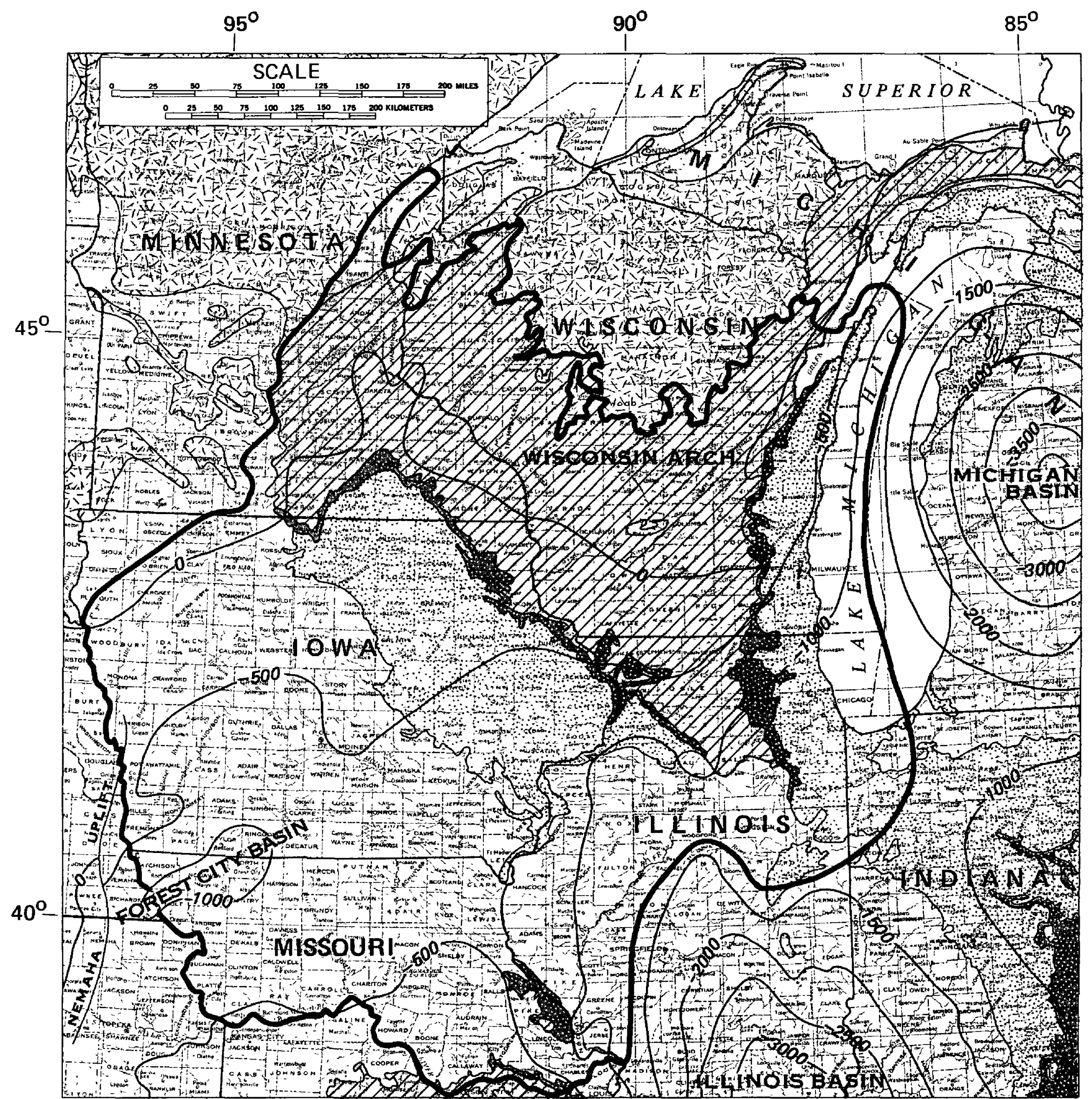

Base from U.S. Geological Survey

U. S. base map, $1: 2,500,000$

\section{r}

Geology modified from P. B. King and H. M. Beikman (1974). Structure from P: B. King (1969)

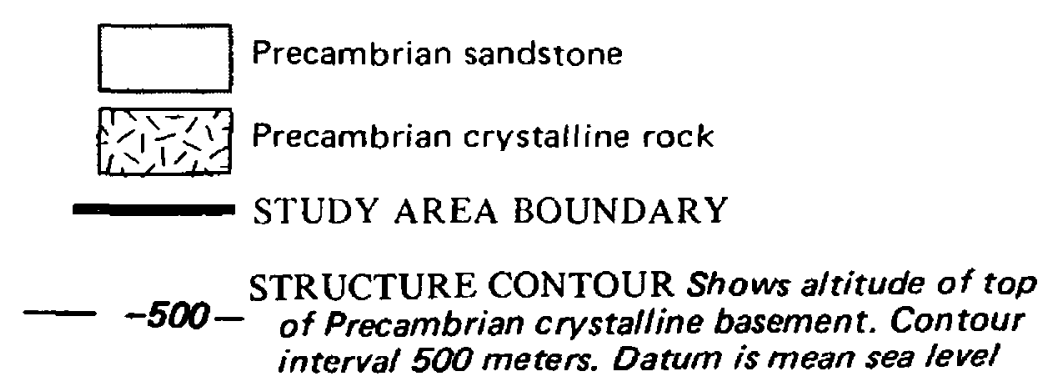

Figure 1. Location and general bedrock geology of the northern Midwest regional aquifer study area. 
The aquifer rocks, particularly the basal Cambrian Mount Simon Sandstone, are thickest in the Illinois and Michigan basins (fig. 1), which were areas of subsidence during deposition. They are thinnest where they feather out against Precambrian rocks in Michigan, Wisconsin, Minnesota, and northwestern Iowa. They also are the uppermost consolidated rock units in most of their extent in Wisconsin, in extreme northern Illinois, in southeastern Minnesota, in extreme northeastern Iowa, and along the lower reaches of the Missouri River in Missouri; elsewhere these rocks are overlain by the Maquoketa Shale or younger rocks (fig. 1). The aquifer is artesian beneath the shale, but elsewhere is under water-table or semiartesian conditions.

\section{PROBLEM}

The Cambrian-Ordovician aquifer system supplies a major part of the water needs in the northern Midwest. Many metropolitan areas depend on the aquifer for all or part of their water supplies. Included are the MilwaukeeWaukesha, Madison, and Green Bay areas in Wisconsin; the Des Moines, Fort Dodge, Mason City, and Cedar Rapids-Iowa City areas in Iowa; the northeastern Illinois and Chicago areas; and the Minneapolis-St. Paul area in Minnesota. In addition, many cities, villages, and farms depend on ground water, commonly from this aquifer.

The potentiometric head in the aquifer has declined hundreds of feet in the heavily pumped Chicago-Milwaukee region and to a somewhat lesser extent in the other heavily pumped areas. Projections of future water needs indicate continuing or increasing demands and, therefore, continuing water-level declines.

The aquifer contains highly mineralized water in several places, especially in its deepest parts, generally coinciding with regional discharge or structurally low areas, and mainly in the southwestern, southern, and southeastern parts of the study area. Water from the highly mineralized zones may be induced into fresh-water zones by large withdrawals of fresh water, such as in northeastern Illinois, southeastern Wisconsin, and central Iowa.

Protection and management of the aquifer system are important concerns of State and local planning, regulatory, and water-management agencies. Sound management decisions require a thorough understanding of the aquifer system--its physical dimensions, hydrologic characteristics, water availability, water quality, and the effects of past and future pumping from the aquifer. Many investigations of the aquifer have been made within the U.S. Geological Survey's cooperative programs in Iowa, Minnesota, and Wisconsin, and by the State Geological Survey and State Water Survey in Illinois. Most, however, relate only to those parts of the aquifer lying within each State. A regional study is necessary for a comprehensive understanding of the aquifer and its response to development. To this end, the aquifer is 
included in the U.S. Geological Survey's program of Regional Aquifer-System Analysis (RASA), authorized by Congress in fiscal year 1978. This report describes the objectives, work plan, and organization of the study.

\section{OBJECTIVES}

To evaluate the water-supply potential of the aquifer and to be able to evaluate regional aquifer response to changes in ground-water development, the study will pursue these objectives:

1. Describe the geologic, hydrologic, and chemical-quality characteristics of the aquifer system

2. Develop a regional data base and computerized datamanagement system

3. Define the predevelopment hydrologic system and detail the changes caused by development

4. Determine past and present withdrawals from the aquifer and estimate future water demand

5. Develop digital-computer models that will simulate the aquifer system

6. Estimate effects of continued and future stress on the aquifer system

7. Use simulation techniques to evaluate alternative management schemes for extending the useful life of the aquifer system

8. Evaluate hydrologic data monitoring and develop a network to monitor future water use, water levels, and changes in water quality

\section{APPROACH}

The objectives of the study will be met by: 1) compiling and analyzing geologic, hydrologic, and water-quality data, 2) collecting and analyzing new data where needed, 3) developing computer models of the aquifer system, and 4) evaluating past and future impacts from development of the aquifer.

Hydrologic characteristics and interrelation of individual rock units within the aquifer system, which vary regionally, will be studied in detail. Confining beds and overlying aquifers also will be studied in the 
detail necessary to understand their relation to the aquifer system. Stratigraphic, hydraulic, water-quality, water-level, and water-use data will be collected and analyzed.

A regional digital model will be developed, as well as local models of areas of heavy pumping and large water-level declines. The models will help to define the prepumping flow regime and resultant changes caused by pumping, and will be used to predict hydraulic effects of future pumping, artificial recharge, or other stresses on the aquifer system.

\section{ORGANIZATION}

The 4-year study will be made from October 1, 1978, to September 30 , 1982 , by a central project staff of the U.S. Geological Survey in Madison, Wis. The staff will work closely with Survey personnel on supporting subprojects in District offices in Illinois, Indiana, Iowa, Minnesota, Missouri, and Wisconsin. Each subproject will be funded by the central project; however, funds cannot be used to match local or State funds. Additional work may be contracted with State agencies. An attempt will be made to collect water-level and geochemical data in western Michigan and the extreme southeast and northeast corners of Nebraska and Kansas in order to refine mode1 boundaries.

The central project staff will design the regional study in coordination with each participating Survey District. The staff will be responsible for the operation of the project and will coordinate the work in each District to insure that adequate data will be generated on schedule. Regional computer models and a local model of northeastern Illinois and southeastern Wisconsin will be designed and operated by the project staff.

The District subproject staffs will be responsible for the collecting, processing, and primary interpretation of data for the aquifer system within each State. Maps will be supplied to the central project for meshing on a regional basis. Computer models of local aquifer systems will be developed within the District subprojects as needed.

\section{RELATION TO OTHER STUDIES}

Much of the knowledge of ground-water resources in the project area is a result of the State-Federal cooperative program of the U.S. Geological Survey. The Illinois State Geological Survey and Illinois State Water Survey historically have had strong programs of ground-water investigation. This project will depend on the active participation of State investigative agencies such as these and State regulatory and water-management agencies.

The project will be coordinated with related cooperative projects in the participating Districts, such as a ground-water model study of the Twin Cities area in Minnesota, a proposed ground-water-quality study in Wisconsin, 
an ongoing Cretaceous aquifer study and an upcoming Silurian aquifer study in Iowa, and water-use studies in all Districts.

To help facilitate local cooperation and insure that local interests are considered, representatives from each State will be invited to join a liaison committee. It will meet at least annually for a report on the plans and progress of the project and to provide local input to the project.

\section{AREA OF STUDY}

The project will encompass about 161,000 square miles in parts of six States (fig. 1). In those States, the Cambrian and Ordovician rocks form a contiguous aquifer unit from which fresh to moderately mineralized water is withdrawn for many uses. The northern boundary of the study area in Wisconsin, Minnesota, and northwestern Iowa is the remnant eroded edge of Cambrian rocks overlying Precambrian crystalline rocks, except for the inclusion of the Hinckley Sandstone in Minnesota. The other boundaries are subject to change as hydrogeologic data are collected. The western and southwestern boundary is the Missouri River, because water from the aquifer system probably discharges into some reaches of the river. The southeastern and eastern boundary in Illinois, Indiana, and Wisconsin is placed arbitrarily at about the minus 1200 -meter structural contour on the Precambrian basement (fig. 1); south and east of this boundary the aquifer is not used because the water is highly mineralized and is a brine in the deeper parts of the Illinois and Michigan basins. The northeastern boundary is along the Menominee River (boundary between Michigan and Wisconsin) because the river probably is a discharge line. The flow system in the Upper Peninsula of Michigan is, therefore, localized and not part of the major contiguous aquifer unit. An attempt will be made to collect hydrologic data, particularly geochemical and water-level data, in the western part of the Lower Peninsula of Michigan (Michigan basin), central Illinois (Illinois basin), and extreme southeastern Nebraska and northeastern Kansas (Forest City basin). If the data warrant, the arbitrary boundaries will be changed.

\section{PLAN OF STUDY}

Work activities are shown in the following outline and a schedule of the major elements is shown on figure 2.

A. Planning

1. Develop detailed work plan and budget for central project team

2. Finalize subproject proposals and allocate funds to each participating Survey District 


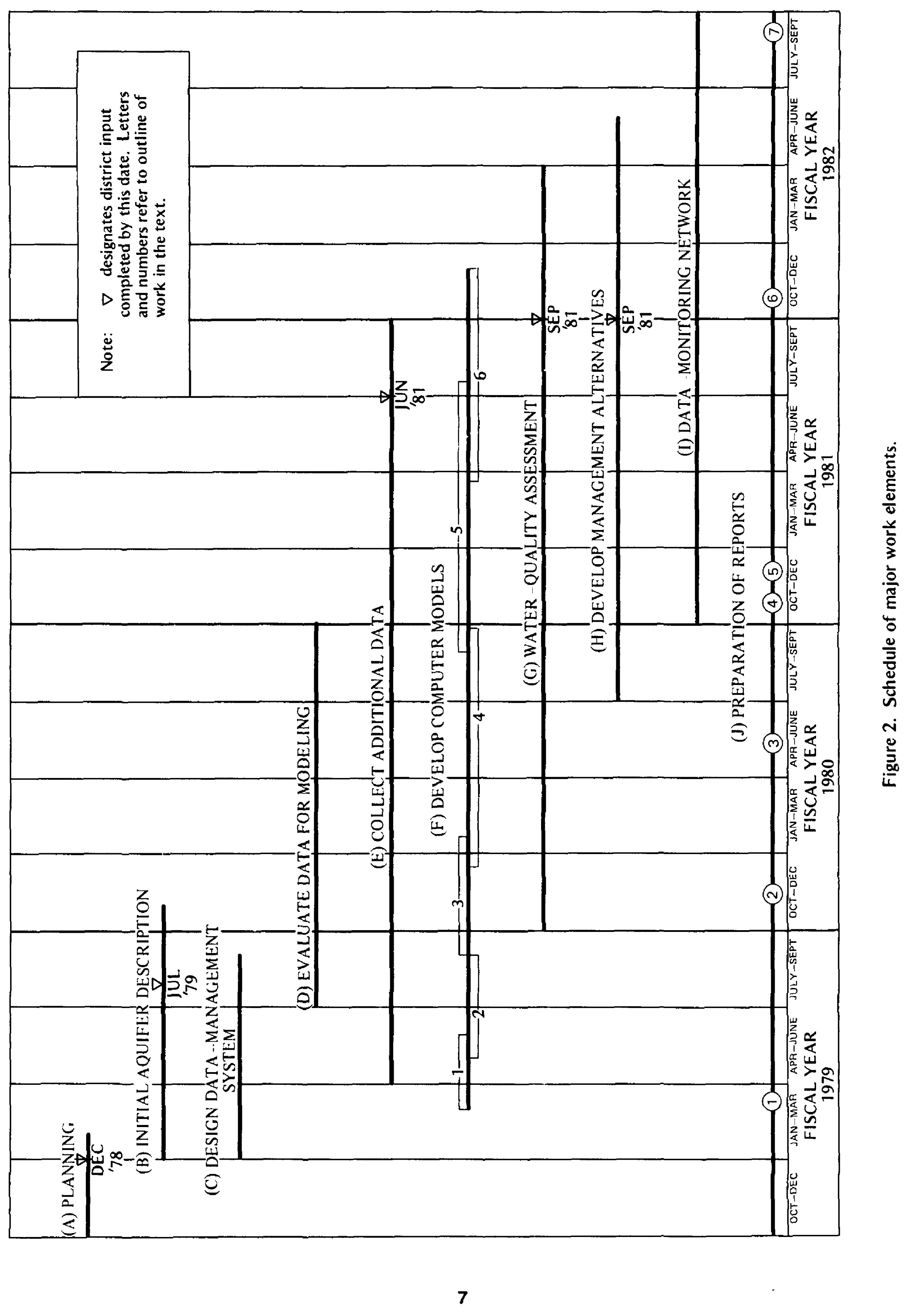


3. Organize regional liaison committee

4. Assess equipment needs of Districts and project

5. Organize stratigraphic nomenclature committee

6. Determine regional and District base-map needs and obtain required maps

7. Coordinate with water-use studies

8. Investigate feasibility of contracting out selected work

B. Initial description of aquifer

Each District will assemble and compile data from files and publications for an initial description of the aquifer system. These compilations will be meshed into regional maps, which will indicate data deficiencies and aid in planning further data collection.

1. Assemble and map readily available geologic data

2. Estimate and map the hydraulic properties of aquifer units and confining beds from available data

3. Determine or estimate predevelopment recharge, discharge, and head conditions

4. Assemble and map available water-quality data

C. Design computerized data-management system for storage and retrieval of interpolated data

1. Determine project data-storage and retrieval requirements

2. Review data-storage and retrieval systems

3. Develop, adapt, and revise a data-management system

D. Evaluate adequacy of data for modeling and place in a computerized data-management file

1. Regionalize data for use in models

2. Digitize and enter in computer management file

3. Determine additional data needs 
E. Work with Districts to establish programs to collect additional data

The major data deficiencies are the hydraulic properties, vertical head distribution, and variability of chemical characteristics within the aquifer system. It is anticipated that the regional project will use inflatable packers in wells to obtain the vertical distribution of head and water quality in the aquifer system.

1. Improve and update structure contour, isopach, and facies maps

2. Improve maps of aquifer properties

3. Obtain historical pumpage data where the aquifer system is confined or where pumping has lowered the potentiometric surface

4. Obtain current (1979-80) pumpage and water-1eve1 data for the entire aquifer system

5. Prepare potentiometric maps

6. Update water-quality maps and plan geochemical studies to include inorganic and organic interactions that may be significant

F. Develop computer models of the aquifer system

1. Select suitable digital-computer modeling program, set it up on computer, make modifications as necessary, and make it operational for this study

2. Develop conceptual model of the aquifer system

a. Establish boundaries and possible natural divisions into separate model segments

b. Determine appropriate scale (possibly a hierarchy of scales, starting with very coarse grid)

c. Design layers to approximate the three-dimensional relation of aquifer subunits and their confining beds

3. Test conceptualization of regional aquifer system by approximating predevelopment conditions with a steadystate simulation 
4. Develop cross-sectional models to test flow concepts and boundary conditions. Apply sensitivity analysis to preliminary 3-D model to determine most important hydrologic parameters and data needed

5. Finalize regional model, incorporating additional data from District subprojects and from related cooperative projects

a. Calibrate model with historical water-1evel and pumpage data

b. Generate boundary conditions for local models

6. Finalize Illinois-Wisconsin-Indiana model

G. Regional assessment of water quality

1. Update and finalize maps of chemical-quality characteristics

2. Relate the chemical composition of water in the aquifer to the flow system

3. Use geochemical models, such as WATEQF and PHASEQ, to determine relation between water quality and aquifer mineralogy

4. Determine distribution of significant radioelements, trace metals, and organic carbon in the aquifer system

5. Study the saline water to define its characteristics, occurrence, and potential movement to fresh-water zones

6. Attempt to determine past effects on water quality owing to development of the aquifer

H. Develop optimum aquifer management alternatives

1. Develop projections of water demand to the year 2000 or 2010 in conjunction with State and local agencies and use the projections to simulate the aquifer response 
2. Determine distribution of pumpage to minimize drawdown and adverse changes in water quality

3. Determine the "sustained yield" of the aquifer by computer simulation

I. Develop data-monitoring network

1. Design and operate a data-collection network to monitor water-level and chemical-quality changes caused by withdrawals from the aquifer

2. Plan for the continuation of data collection by Districts after project termination by including network in the Federal observation well program

3. Plan a followup program to analyze network data and evaluate the predictive capabilities of the computer models

J. Report preparation

1. Report on plan of study (WRI)

2. Report on data management system developed for the study (open-file)

3. Preliminary report on regional hydrogeology (open-file)

4. Report on results of cross-sectional modeling (open-file)

5. Report on results of geochemical reaction modeling (open-file)

6. Report on results of steady-state 3-D mode1 simulations (open-file)

7. Final project report (Professional Paper) If warranted, other reports of interest will be released to the open file or published in scientific journals.

\section{COMPUTER MODELS}

Computer models of the aquifer system will be developed to predict future effects on the aquifer due to alternative plans of withdrawal. In addition, the models will help to define the hydrologic system better, allow the best use of data, and show where additional data needs to be collected. 
The initial regional model will have an extremely coarse grid and will be operated in a steady-state simulation to approximate predevelopment conditions. Initial estimates of aquifer properties, areal recharge, natural discharge, and head distribution will be used in the mode1, but will be improved during calibration. As hydrologic parameters are defined better and calibration is improved, the grid size will be decreased, and available pumpage data will be entered to simulate historical drawdown. Areas of data improvement or additional needs will be identified through sensitivity analysis or parameter identification techniques. Historical pumpage and current (1979-80) water levels will be used in the final calibration of the regional model after additional data are collected by District subprojects. Boundary conditions for local fine-grid models will be taken from the regional simulation.

The northeastern Illinois-southeastern Wisconsin-northwestern Indiana area will be modeled by the central project staff, along with the regional modeling. Previous computer models of the aquifer system in this area have been prepared separately in Illinois (Prickett and Lonnquist, 1971) and Wisconsin (Young, 1976). These models, however, focus only on the State in which they were made and are two-dimensional. The new model will emphasize all areas of pumping stress and will integrate the aquifer system in three dimensions irrespective of State boundaries. The areal extent of this model will be minimized and the accuracy of simulation near its boundaries will be improved by using boundary conditions simulated in the regional model.

\section{DISTRICT WORK PLANS}

Each Survey District will follow a plan of study similar to that just described. The work plan for each will be detailed in a project description and will be scheduled to provide timely input to the central project. The amount of new data collection needed in each District will depend on the scope of previous investigations and data-collection programs. Primary areas of study to be emphasized in each District are described below.

\section{ILLINOIS}

The Cambrian-Ordovician aquifer system is a major source of water for municipal, industrial, agricultural, and domestic use in northern Illinois. It is most heavily used in the Chicago area, where the potentiometric surface has declined as much as 800 feet since development of the aquifer began in 1864. Future water demands are projected to increase, resulting in further water-level declines. Some saline water occurs in the Mount Simon Sandstone in northeastern Illinois, and the entire aquifer becomes saline southward in the Illinois basin. This water may be induced into the fresh-water zone by the steep head gradient toward the heavily pumped 
Chicago area. Because of these problems, a detailed knowledge of the aquifer system is needed to protect and manage the aquifer.

Illinois is unique among the States in this study in that all investigations of the aquifer have been made by State organizations and available data are stored in their files. The major agencies are the Illinois State Geological Survey (ISGS) and Illinois State Water Survey (ISWS), who have published numerous reports relating to the aquifer.

Much of the data needed to model the aquifer system in the Chicago area is in the files of these State agencies, and their interpretive reports document the hydrogeology in some detail. The distribution of hydrologic characteristics of aquifers and confining beds, however, need to be determined more completely. The aquifer has been subdivided by the Illinois agencies into the basal Mount Simon aquifer, the overlying Eau Claire confining bed, and the deep sandstone or Cambrian-Ordovician aquifer (the strata between the Cambrian Eau Claire Sandstone and Ordovician Maquoketa Shale). A computer model of the latter aquifer was prepared for the Chicago area by the ISWS (Prickett and Lonnquist, 1971). This model has been updated and is used in water-allocation planning by the Illinois Division of Water Resources. Although the model includes part of southeastern Wisconsin, it was not designed to include pumpage from or accurately simulate the aquifer in Wisconsin.

Data Collection and Analysis

Available data on aquifer and confining-bed boundaries and hydraulic properties, water levels, water use, and water quality will be compiled and reviewed for adequacy. Where needed, additional data will be collected. Vertical variation in aquifer properties, hydraulic head, and water quality will be determined by field testing and sampling in available wells. Methods used will be borehole geophysical logging, and test pumping of and sampling water from isolated zones in the aquifer by the use of inflatable packers. Several pumping tests will be made, especially in areas where transmissivity may be reduced owing to extensive dewatering of the upper parts of the aquifer. All available data will be tabulated or compiled into maps to describe the hydrogeology of the aquifer system.

\section{Computer Models}

As previously stated, the Chicago area will be modeled in conjunction with southeastern Wisconsin and northwestern Indiana by the central project staff. The District, however, may develop some local models and may do some cross-sectional modeling to estimate hydraulic parameters and determine fresh-salt water relationship. 


\section{Reports}

The Illinois subproject will produce basic-data reports of local interest and a summary interpretive report on the Illinois subproject. In addition, individual reports may be prepared on the results of any local or cross-sectional modeling.

\section{INDIANA}

The Cambrian and Ordovician rocks comprising the aquifer system in Illinois extend into northwestern Indiana, becoming progressively deeper. The aquifer is not a major source of water because the overlying Silurian and Devonian limestones and Pleistocene sediments provide sufficient yields to wells. In addition, the aquifer contains some highly mineralized water that is unsuitable for most uses. Parts of the aquifer containing saline water are used for deep well waste disposal and natural gas storage reservoirs.

The large water-level declines caused by pumping in the Chicago area have extended into northwestern Indiana. Total drawdown has exceeded 500 feet in the northwest tip of Indiana; thus, a significant quantity of ground water is induced from Indiana into Illinois. The mineralized water may be affected by this regional flow pattern and may be encroaching on fresh water parts of the aquifer.

The aquifer system has not been studied in any detail in Indiana. Little is known of the extent of the Chicago-induced drawdown in Indiana, the distribution of saline water, the configuration of the saline-fresh water interface, and the extent of waste disposal in the aquifer.

The northwesternmost five counties in Indiana will be the primary area of study, but some work may be done elsewhere to define the saline-fresh water interface. This study will be coordinated with an ongoing District study of water in the glacial drift and Silurian-Devonian aquifers in Newton and Jasper Counties.

\section{Data Collection and Analysis}

Only a few water wells, mostly unused at present, are finished in the aquifer in the study area; thus, available data will be sparse. Some abandoned and plugged oil wells penetrate the aquifer and may be sources of some water-level and water-quality data, as well as geologic and geophysical logs. Wells that are open or can be opened for nominal costs will be used to determine vertical variations in aquifer properties, hydraulic head, and water quality. Geophysical logs will be made in these wells, and individual units of the aquifer will be isolated with inflatable packers for test pumping and water sampling. 
An inventory will be made of all waste injection into bedrock aquifers in the area.

\section{Computer Models}

This area will be included in both the regional and northeastern Illinois-southeastern Wisconsin models prepared by the central project staff.

Cross-sectional models may be prepared in Indiana to help determine the magnitude of aquifer properties, the vertical components of flow, and the relationship of water salinity to the flow system.

\section{Reports}

A summary report of the study in Indiana will be prepared along with papers on special phases of the study.

IOWA

Sandstones and dolomites of Cambrian and Ordovician age form a significant aquifer system in most of Iowa. The most productive parts of the sequence are the Cambrian Jordan Sandstone and the lower members of the overlying Ordovician Prairie du Chien Formation. The deeper Galesville and Mount Simon Sandstones are major aquifers in the extreme eastern part of the State. Elsewhere, the latter two units probably contain highly mineralized water. Although the Ordovician St. Peter Sandstone yields small to moderate amounts of water in parts of eastern Iowa, it is usually cased off in deep wells because it caves readily. The Ordovician Galena Dolomite is the least significant aquifer, generally yielding only minor amounts of water.

The Jordan-Prairie du Chien aquifer is utilized for water supplies in most of Iowa. The major exceptions are the northwest corner, where it is thin or absent, and the southwest corner, where it is extremely deep. The other aquifers are used moderately in areas where they occur at relatively shallow depths.

Protection and management of these aquifers, the Jordan-Prairie du Chien in particular, is of concern to State officials. Mandates on type of use and allowable drawdown of this aquifer have been issued by the Iowa Natural Resources Council. Thus, a comprehensive study of the CambrianOrdovician aquifer system is needed to better understand its response to development and to provide data upon which future management decisions can be based. 
Data Collection and Analysis

Data to be compiled and analyzed will include geologic information on position, composition, and thickness of individual aquifers and confining beds; water levels for individual aquifers; yield, drawdown, and pumpingtest information; withdrawals; and chemical-quality information. A large part of these data for the principal aquifer, the Jordan, is published as an atlas (Horick and Steinhilber, 1978). The bulk of new data to be collected will be water-level and withdrawal information. Some new geologic and hydrologic information will be obtained by borehole geophysical methods, by packer testing, by flow-meter surveys, and by pumping tests. The geologic and hydrologic data-collection programs will depend on present wells.

Computer Mode1s

Two-dimensional digital models of the Des Moines, Cedar Rapids, and Davenport areas will be prepared in Iowa. These models will help to verify hydrologic parameters and can be used to evaluate various local management schemes. Digital modeling of the aquifer system will indicate data deficiencies that should be corrected, if possible. The models will help to define the predevelopment flow regime and resultant changes caused by pumping and can be used to predict hydrologic effects of future pumping or other stresses on the system.

\section{Reports}

In addition to open-file map reports, a final report will describe the hydrology and water quality of the aquifer system, including water availability and descriptions of local digital models and results. This report also will outline a hydrologic monitoring program that will provide accurate and timely information for future developers and managers.

\section{MINNESOTA}

The main aquifer system to be studied in Minnesota consists of the Cambrian and Ordovician rock units, the overlying Devonian limestones in the south, and, where present, the underlying Precambrian Hinckley Sandstone. The Hinckley and Mount Simon Sandstones form the second most productive aquifer unit after the Prairie du Chien-Jordan aquifer.

The aquifer system underlies southeastern Minnesota and extends into Wisconsin to the east and Iowa to the south. This is the most populous area of the State and has the largest ground-water use, primarily in the Twin Cities of Minneapolis-St. Paul. Although the Twin Cities withdraw water from the Mississippi River for most of their municipal supply, large withdrawals of ground water for industrial, commercial, and suburban municipal supplies have lowered water levels in the Mount Simon-Hinckley and 
Prairie du Chien-Jordan aquifers by 90 and 200 feet, respectively, since 1890. Rapidly expanding irrigation around the Twin Cities, along with increasing ground-water demand caused by population and economic growth, will accelerate drawdown of water levels in the present cone of depression.

In some areas, the Mount Simon-Hinckley aquifer contains water high in sodium and chloride and has dissolved-solids concentrations exceeding 2,000 milligrams per liter.

The aquifer system has been studied in detail only in the Twin Cities area (Liesch, 1961, and Norvitch and others, 1973), but all or parts of 13 U.S. Geological Survey Hydrologic Investigations Atlases of watersheds in Minnesota cover the entire project area. Coincidentally, a 3-year District project in cooperation with the Metropolitan Council of the Twin Cities Area is now beginning. It will produce a comprehensive three-dimensional computer model of the ground-water system in the seven-county Twin Cities area. The regional and Twin Cities studies will be closely coordinated.

Data Collection and Analysis

All hydrogeologic data concerning the aquifer system will be compiled from available reports and from the files of the Geological Survey and several State and local agencies. Additional data will be collected, where needed.

\section{Computer Models}

The major model will be that of the Twin Cities prepared by the District. The regional model will include the entire aquifer area in Minnesota.

$\underline{\text { Reports }}$

Where feasible, data reports will be prepared locally. A summary interpretive report will describe the results of the study in Minnesota.

\section{MISSOURI}

The rock units comprising the Cambrian-Ordovician aquifer in Iowa and Illinois also extend under most of Missouri. They generally contain saline water and are deeply buried by younger Devonian, Mississippian, and Pennsylvanian rocks north of the Missouri River. The aquifer is not as deeply buried, and fresh water is obtained from it in a six-county area near the Missouri River in eastern Missouri. The Missouri and Mississippi Rivers may be lines of regional discharge from the aquifer, but the fresh-water area seems to contradict that theory. The aquifer will be studied north of the Missouri River to determine its relation to the regional flow pattern 
and water quality in Iowa and Illinois. The aquifer has not been studied in detail in this area.

Pumping from the aquifer for public supplies has caused cones of depression to form around several cities. About 30 municipalities obtain water from the aquifer, and irrigation and industrial uses are increasing.

An ongoing cooperative study of the water resources in Audrain County and a planned study of the shallow aquifers in northwestern Missouri will be coordinated with this study.

Data Collection and Analysis

Geologic, hydrologic, and water-quality data will be compiled and tabulated from publications and the files of the Geological Survey and State agencies. Additional well data will be collected where possible. The aquifer system and quality of water relation will be described by maps and cross sections. Water-use data will be compiled.

Reports

A summary interpretive report will describe the hydrogeology and water-quality relations of the aquifer system in northern Missouri.

\section{WISCONSIN}

The Cambrian-Ordovician aquifer system underlies two-thirds of Wisconsin and is a major source of water for municipalities, industries, irrigators, farms, and homes. It is artesian where confined by the overlying Maquoketa Shale along the east edge of the State. The potentiometric surface in the Milwaukee and Green Bay areas has declined greatly because of large-scale pumping. The decline in southeastern Wisconsin is partly due to pumping from northeastern Illinois. Few detailed studies have been made of the aquifer in Wisconsin except in southeastern Wisconsin, Green Bay, and Madison.

Some very mineralized water occurs in deep parts of the aquifer near Lake Michigan, Lake Winnebago, and in southwestern Wisconsin. The geochemical occurrence, distribution, and potential for movement of this water will be studied.

A long-term study of the water quality in all aquifers in the State is now beginning, in cooperation with the Wisconsin Department of Natural Resources. This study will be coordinated closely with the regional study. 
The Wisconsin subproject will collect and compile hydrogeologic, water-quality, and water-use data on the aquifer system. Additional data will be collected where needed. Data deficiencies in Wisconsin are primarily the hydrologic characteristics of the aquifers and confining beds and vertical head and water-quality distribution. Inflatable packers will be used in available wells to test and sample 1solated zones in the aquifer. The thickness of the lowermost unit of the aquifer, the Mount Simon Sandstone, is unknown in southeastern Wisconsin. However, the thickness can be obtained if the depth to the Precambrian basement surface can be determined by seismic surveys.

\section{Computer Models}

The major area in the State to be modeled is the southeast, which will be done, along with northeastern Illinois, by the central project staff.

The Wisconsin subproject will model the aquifer system in the lower Fox River valley from Lake Winnebago to Green Bay. A model of the aquifer limited to Brown County was prepared recently by a consultant; however, the aquifer in the surrounding area is also developed extensively, and knowledge about it is lacking.

\section{$\underline{\text { Reports }}$}

Local data reports and maps will be prepared during the study, and a final interpretive report on the aquifer system will summarize the Wisconsin part of the project. A separate report will document the groundwater model of the lower Fox River valley. 


\section{REFERENCES}

Horick, P. J., and Steinhilber, W. L., 1978, Jordan aquifer of Iowa: Iowa Geological Survey Miscellaneous Map Series 6, 3 sheets.

King, P. B., compiler, 1969, Tectonic map of North America: U.S. Geological Survey map, $1: 5,000,000$.

King, P. B., and Beikman, H. M., compilers, 1974, Geologic map of the United States: U.S. Geological Survey map, 1:2,500,000.

Liesch, B. A., 1961, Geohydrology of the Jordan aquifer in the MinneapolisSt. Paul area, Minnesota: Minnesota Department of Natural Resources, Division of Waters Technical Report 2, p. 24.

Norvitch, R. F., Ross, T. G., and Brietkrietz, Alex, 1973, Water resources outlook for the Minneapolis-St. Paul metropolitan area, Minnesota: Metropolitan Council of the Twin Cities Area, 219 p.

Prickett, T. A., and Lonnquist, C. G., 1971, Selected digital computer techniques for groundwater resource evaluation: Illinois State Water Survey Bulletin 55, 62 p.

Young, H. L., 1976, Digital-computer model of the sandstone aquifer in southeastern Wisconsin: Waukesha, Southeastern Wisconsin Regional Planning Commission Technical Report 16, 42 p. 


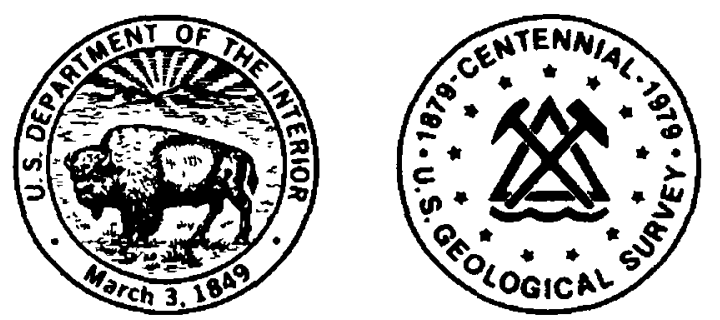